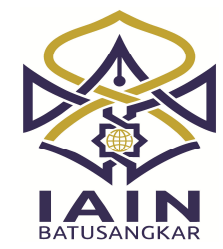

JURNAL TA'DIB, Vol (1), 2017, (Januari-Juni)

(Cetak ISSN 1410-8208 Online ISSN 2580-2771)

Tersedia online di http://ecampus.iainbatusangkar.ac.id/ojs/index.php/takdib/index

\title{
An Analysis of Lesson Plans Written by English Student- Teachers for Young Learners
}

Zulhermindra*)

Institut Agama Islam Negeri

Batusangkar, Sumatera Barat, Indonesia

E-mail: zulhermindra@yahoo.com

\section{Rahmawati*}

Institut Agama Islam Negeri

Batusangkar, Sumatera Barat, Indonesia

E-mail:rahmawati@iainbatusangkar.ac.id

\begin{abstract}
Abstrak: This study is to describe the application of consistency principles in developing lesson plans of teaching English for young learners designed by student-teachers. The design of this research is descriptive quantitative. The instrument in this study is a checking guide sheet. The lesson plans, as data, were analyzed by comparing the consistency principles of developing lesson plan of teaching English for children with each document. Based on the analysis, there were 23 documents (38\%) applying most of the principle of consistency within the development of the syllabus and only 1 document (2\%) which does not apply any of the principles. In detail, 25 documents (42\%) partially applied the principle of linkage and integration and no document (0\%) which did not apply any of these principles. Then, 28 documents (47\%) applied all of the principles of learning foreign languages for children and no document (0\%) that did not apply any of the principle. Almost all documents (92\% - 93\%) implemented each principle of helping students' development and practice language through collaboration, integrate language and content, and validate and integrating that learning with the learners' language and culture. Next, most of documents (68\% - 78\%) applied the principles of providing an active and fun role in the learning experience, using multidimensional and thematic learning activities, validating and integrating the learning with language and culture of learners, and providing clear objectives and feedback on the language usage. In conclusion, the application of the principles of learning English for children lies in the range of $81 \%$.
\end{abstract}

Keywords: Lesson Plan, Student-Teachers, English for Young Learners

\section{INTRODUCTION}

Introducing English in elementary level in Indonesia is positively welcomed. In fact, most primary schools in Indonesia make English the preferred subject for local content, although the 2013 curriculum no longer recommends English as a local content subject. However, it is necessary to anticipate some potential problems in learning English for children in Indonesia. One of them is the unavailability of qualification requirements for teachers who teach English in elementary school. Kasihani
(2001: 233-234) suggests that most teachers who teach English in elementary school are those who have not received special training on the teaching of English. As a result, the ability to teach English is very limited because it lacks sufficient scientific background, especially with regard to teaching methodology.

In line with above phenomena, Rosenbusch (2000) emphasizes that there are several other factors that need to be anticipated in the planning of foreign language learning at the level of basic 
education, including: (1) the lack of skilled teachers with sufficient language skills (2) qualifications in teaching the language (3) inadequate learning materials, and (4) lack of evaluation procedures for the students, teachers and the program itself.

Looking closely at the challenges associated with potential English learning problems for children, especially for elementary school students, the English Teaching Program provides students with the knowledge and skills to teach English at all levels of education including basic education. Specifically, English for children is designed to equip students with theoretical and practical knowledge and skills related to learning English for young learners, including approaches / methods / language teaching techniques, instructional material development, instructional media, learning process preparation, microteaching by using songs, games and stories. While the lecture activities include the presentation of materials, discussion, observation of English language learning for children in the classroom and its reporting and apprenticeship in the related elementary school. It is expected that students have practical skills to implement English learning for children and are able to select, adapt and develop techniques, materials, media and learning activities for elementary school children.

One of the topics discussed in the course is formulating lesson plan. Students are expected to be able to design syllabus based on their own competency standards and basic competencies by referring to the assigned language skills and developing them into a lesson plan in the form of group work. Furthermore, the task of this group is presented in class discussions, commented on by other groups and given clarification and reinforcement from lecturers. It is expected that through these lectures, each group member can benefit to be applied in the form of individual tasks.

During learning process, it was found not yet maximally understanding of the student-teachers in developing lesson plan. Irrelevant Basic Competency with syllabus or between syllabus and lesson plan is a matter that need to be disclosed since the success of a learning process is determined by planning process of learning. Especially for learning English for children, in the absence of planned, systematic and mature preparation, not only results in the attainment of learning objectives, but also the attitude and motivation of children to learn English at their own pace.

The importance of lesson plan of teaching English for children needs a research to find out the description of student-teachers' lesson plan

The formulation of this research problem is: How is the application of lesson plan consistency principle designed by student-teachers of English for children?

The purpose of the study is to describe the application of consistency principle for teaching English to children designed by student-teachers.

\section{THEORETICAL FRAMEWORK \\ 1. English Language Learning Curriculum for Beginners in Indonesia}

Minister of National Education Regulation No. 41 of 2007 suggests that lesson plan includes syllabus and learning implementation plan that contains subject identity, competency standard, basic competence, indicators of competency achievement, learning objectives, material teaching, time allocation, advocacy methods, learning activities, assessment of learning outcomes, and learning resources.

\section{Principles of Developing Syllabus and Lesson Plan}

In the development of the syllabus needs to be considered several principles. The principle is a rule that will animate the implementation of educational unit level curriculum. There are several principles that should be the basis for the 
development of this syllabus: scientific, relevant, systematic, consistent, adequate, actual / contextual, flexible, and comprehensive.

Furthermore, the lesson plan is outlined from the syllabus to direct the learning activities of learners in order to achieve basic competence. In order for planning to deliver expected results, there are principles of the lesson plan preparation that need to be considered, namely: a) Taking into account individual differences of learners, b) Encouraging active participation of learners, c) Developing a culture of reading and writing, d) Providing feedback and follow up, e) The linkages and integrity of the lesson plan are prepared by considering the relevance and integrity of Standard Competency, Basic Competency, Learning Materials, Instructional Learning, Indicators of Competency Achievement, Assessment, and Learning Resources in a whole learning experience, Implementing information technology and communication.

\section{Characteristics of English Language Learning Planning for Beginners}

In planning for beginner English learning, teachers should consider experts' opinions about their characters. The following describes views pertaining to novice learners.

Philips (in Nagy, 2011: 1) states that young learners are children entering the early school age (5 or 6$)$ - (11 or 12). Cameron (2001) also noted that young learners are children under the age of 14 . Furthermore, Kasihani (2007: 15) also suggests that young learners are elementary school children between 6-12 years old.

According Kasihani (2007: 15-20) characteristics of beginner learners in general is: at first the children liked the lessons related to their lives. But as they get older, they start paying attention to others, so communication starts to open. In addition, children are still difficult to distinguish between the concrete and the abstract. Nevertheless, children love the imaginative things. Children are known for their favorite games, stories and songs. but they feel bored quickly. So the teacher should consider the diversity of learning activities. In learning they are not yet fully able to cooperate in learning, but they are comfortable learning if there are friends nearby. As their age increases, their ability to cooperate and learn groups increases. At the age of 8-9 years, they are ready to learn a foreign language such as English.

Stocker (2007) provides tips on teaching foreign languages to children; 1) engage students in contemporary activities 2) avoid talking for long periods, 3) children learn by interacting with other children and with teachers 4) repeatedly reading material, 5) student motivation to correct their own mistakes and others, 6) empower what has been learned in different contexts. .

Halliwell (2009: 1) adds that basically, kids love to share their experiences; they will be happy if people pay attention to them and what they are talking about. Therefore, it is fitting for a teacher who teaches children to give their full attention and try to understand what they are trying to explain.

Cameron (2001) argues that children have tremendous potential to master a particular language and they have a degree of mastery beyond what we imagine. Cameron further pointed out is the false assumption that children can only master simple language such as counting the mention of color, bernmyanyi, and simple conversation. They have a much greater potential.

According to Mc.Closkey (2005: 79), English teachers for children should consider 7 principles: 1) provide an active and fun role, 2) help students develop and practice language through collaboration or cooperation; 3 ) use learning activities that are multidimensional and thematicly designed, 4) provide understandable input 
through modeling, 5) integrate language and content, 6) validate and integrate the learning with the language and culture of the learner and 7) provide clear objectives and feedback on use of student language.

From the experts' opinion above about the characteristics of early English learners, a teacher in planning his learning should not be careless with these things.

\section{RESEARCH METHODS}

This type of research is descriptive quantitative. The data of this research is taken from the semester test documents English for Children Study English Department STAIN Batusangkar Academic Year 2013/2014. The 60 copies of documents cover the standard competency, basic competence, syllabus and learning implementation plan obtained from the lecturer of the subject. The key instrument in this study is the researchers themselves. To help collect data, researchers use checklists. Data collection techniques used are document checking. The research steps are: a) Sorting and assigning the document to be the object of research, b) Labeling and disguising the author's name, c) Preparing the blanks of the analytical tool, d) Performing the blank guided analysis available, and e) concluding. After the documents are sorted and the analytical forms have been prepared, the stages of data analysis are comparing each document with the consistency principle in syllabus development, the principle of linkage and integration in the development of the lesson plan.

\section{RESULT AND DISCUSSION}

From the analysis of lesson plan it was found that 23 documents (38\%) have implemented most of the principle of consistency within the development of the syllabus and only 1 document (2\%) which did not apply any of consistency principle. Furthermore, 25 documents (42\%) have partially implemented big principle of linkage and integration in lesson plan and no document $(0 \%)$ which do not apply any of these principles. Finally, 28 documents $(47 \%)$ have been apply all of the principles of learning foreign languages for children and no documents $(0 \%)$ that did not apply any of the principle. almost all documents $(92 \%$ - 93\%) have implemented each principle of helping students' development and practice language through collaboration, integrate language and content, and validate and integrating that learning with the language and culture of the learner. While most documents $(68 \%-78 \%)$ have applied the principle provide an active and fun role in the learning experience, using learning activities that are multidimensional and designed thematically, validate and integrate such learning with language and culture of learners, and providing clear objectives and feedback on usage language of students. In general, the application of the principle lies in the percentage range $81 \%$. That is, almost all documents have applied the principles of learning English for children.

Some research findings can be described as follows:

a. There is consistency between basic competencies, indicators, subject matter, learning experience, learning resources, and assessment systems.

It is seen in the examples of syllabus development documents, the underlined words below indicate consistency among basic competence (indicating likes / dislikes), indicators, subject matter, learning experiences, learning resources, and assessment systems.

b. There is no consistency between basic competencies with indicators, subject matter, learning experiences, learning resources and assessment systems 
As it can be seen in the following quotation:

"Kompetensi Dasar

2.2 Bercakap-cakap untuk meminta/memberi jasa/barang secara berterima yang melibatkan tindak tutur: meminta bantuan, meminta barang, dan memberi barang"

Basic competencies:

[2.2 Competent to request / deliver services gratefully involves speech acts: asking for help, requesting goods, and delivering goods]

While the indicators are:

1. Melafalkan kata-kata tentang meminta bantuan dalam bahasa Inggris secara sederhana

[1. Pronouncing words about asking for helps in English simply

2. Melafalkan kata-kata tentang meminta barang secara sederhana

[ Pronouncing words about asking for goods simply]

3. Melafalkan kata-kata tentang memberi barang secara sederhana

[Pronouncing the words about giving things simply] follows:

And the learning materials as

Pronunciation: melafalkan kata-kata meminta bantuan, meminta dan memberi barang dalam bahasa Inggris secara baik dan sederhana.

[Pronunciation: pronounce words asking for help, requesting and delivering goods in English well and simple.]

Example:

- Can you help me?

- May I borrow your pen?

- Etc.
Above quotation indicates that the expected competence is conversation, not just pronunciation

c. There is consistency between basic competence with subject matter / learning, learning experience, and assessment system and learning resource but not with indicator

The example is shown in the quotation below:

Kompetensi Dasar

\subsubsection{Bercakap-cakap untuk meminta/memberi informasi secara berterima yang melibatkan tindak tutur: menanyakan jumlah}

[Basic competencies

\subsubsection{Dialogue to request / inform information correctly that involve the speech acts: asks the amount]}

While the indicator is only written:

"Menanyakan jumlah dalam bahasa Inggris".

["Asking for amount in English".]

This shows that what is to be achieved in basic competencies is not followed clearly by the indicators. Preferably, the indicator is written that the student is capable of conversing which involves a speech act asking the amount.

d. There is no consistency between basic competencies with indicators, subject matter, learning experience, learning resources, and assessment systems

Where indicators, subject matter, learning experiences, and learning resources are simply rewritten as to what is in the basic competencies without explaining each according to 
the function of the syllabus development component.

The lesson plans were prepared by considering the interrelation and integration between core competencies and basic competencies, learning materials, learning activities, assessment, and learning resources in a whole learning experience. Some research findings can be described as follows:

e. Indicators and Objectives are not related to Basic Competencies

In relation to the relevance and integrity of this lesson plan component, the Indicators and Learning Objectives are not related to the Basic Competency because the scope has provided the quality of competence to be achieved while the written indicators and learning objectives do not cover those qualities.

f. Indicators, Learning Objectives and Learning Activities are different from Basic Competency

In the document, the Basic Competency requires students to read loudly with the words, pressure and intonation appropriately and acceptable. In contrast to indicators, learning objectives and learning activities do not emphasize those three things correctly and gratefully. The development capability should focus on understanding the text and the addition of vocabulary. This shows that the Lesson Plan has not been developed consistently.

\section{g. Learning Activities are inconsistent} with Assessment

In this case, the subject matter is presented textually so that it tends to show a high level of difficulty because too many expressions of thanks you to be learned. While in the core activities were written that the teacher explains the material about gratitude. This illustrates that teacher will use a lot of time to explain verbally. Consistency between learning and assessment activities does not exist because in the core activities, it is not planned the achievement of speaking activities such as: communication, interaction.

h. Core activities are inconsistent with Competency Indicators, Learning Objectives and Basic Competencies

In the document, it can be understood that the basic competencies, indicators and learning objectives show the competence to be achieved is the reading skill, however, the core activities of students are not required to read. This is seen in elaboration activities that begin with the teacher's explanation of the adjectives and their functions. Then the teacher guides the students to play "Bingo Game" where students are told to prepare a paper and draw 16 boxes on it. Teachers will mention adjectives otherwise students competently write the word on the board. Who can form words horizontally and vertically then he is the one who won the game. This illustration does not focus on reading but more on listening and writing. Assessment does not refer to basic competency, indicators and learning objectives because in the assessment there is a rubric of temporary "writing" assessment on basic competency, indicators and learning objectives are only related to reading only. The subject matter written on the teaching materials is attached to learners at a high level because it is taken from the internet without considering the learner's low level of analysis. Teaching material that 
presents the definition of adjectives and the types of properties theoretically in English that can not be understood beginner students of elementary school class IV semester II.

i. Inconsistency of Learning Activities and Media Activities with Basic Competencies and Learning Objectives

In the document it was written that the learning objectives that contain the competence to talk about instructional materials "providing instruction and response" illustrate the demands of the learners in order to be able to express a command. But prospective teachers designed a "listening" exercise about a conversation between two friends who met. The incomplete sentence is meant to train the students to know the vocabulary that is not about expressing the word.

From the key answer consisting of 5 pieces of items are: I'm fine, football, hobby. guitar, and string, indicating the inconsistency of goals set by assessment. It also occured between basic competency and learning objectives. Basic competency and above learning objectives are "students can respond very simple instruction verbally". Furthermore, learning activities and media used more contribute to the activities of speaking than listening activities as mandated by basic competencies.

j. Inconsistency of the Lesson Plan between Learning Indicators and Purposes

In this case the indicators and learning objectives were not related to the subject matter. It can be seen from the existing material that not accommodate the competence of the learner to master the way of reading simple sentences, while the indicators and learning objectives exist. It was in the core activities of teachers plan for students to learn to read simple sentences. Furthermore, material coverage on the lesson plan was too widespread because prospective teachers took the material from online sources that have not been modified according to the given basic competency. The quality level of material is very high while new learning material is still at a basic level.

\section{k. Teaching and Evaluation Materials are not Consistent with Basic Competencies}

In this case. teaching materials and the level of difficulty test on evaluation was not linked with basic competency because the it listed competence that will be achieved there was a short reading of a very simple short functional text, while the teaching materials attached the definition of generic structure and descriptive text as well as on the evaluation attached all the text consisted of difficult sentences. The text consists of texts followed by various punctuations such as one long sentence with some difficult vocabulary.

\section{l. Inconsistency between Teaching Materials with Basic Competencies and Learning Objectives}

In the document it was written that the the basic competence and the learning objectives were not related or inconsistent with the teaching materials that were written in basic competence of the lesson plan which required the students to be able to respond to instructions and information very simply with both 
the action and the language. The objective of learning expects students to respond by writing what they hear. The purpose of this material showed the skill of listening and writing while the teaching material contains the expression "order and request" with the instruction "listen and do". This is clear, directing the skills of "listening" and "speaking" and is by action rather than written.

The learning activities described in the lesson plan were too succinct so it can not be clear whether the future teacher will be easy in guiding the students to achieve the learning objectives. For example, prospective teachers make learning activities in the elaboration stage in the form of group activities for dialogue exercises, but it was not explained which dialog guides will be done learners.

\section{m. Inconsistency between Learning Materials and Competency Standards}

The context of the subject matter is inconsistent with the competency standard. Standards of competence restrict the material context to express instruction and information within the school context. On the contrary teaching materials expand the scope in the context of office work or other public places such as the phrase "let's go the movie or how about to go to beach" and others. This also happens to the rating item.

\section{n. Assessment Aspect Inconsistent with Standard Competence - Basic competence}

In Standard-Competence Basic competence, it was shown that the skill to be trained was "reading" competencies. It can be seen from the statement: "to understand sentences, written messages and descriptive text very simple precisely and gratefully" while the written rubric consists of indicators of "smoothness of speech, vocabulary and spelling ". It showed their inconsistency. The assessment aspect should focus more on the ability to "understand" than what has been written. It was also supported by teaching materials that contain comprehension questions.

\section{o. Inconsistency between Basic Competent and Assessment}

It is written in the document that the assessment rubric for "reading aloud" is designed by the prospective teacher without consideration of its interrelationship with the basic competency "conversing to request / inform acceptably which involves the act of" banning "speech. On the other hand, the learning activities were developed too broadly so that they could not provide complete information about teaching materials. For example, on elaboration activities and teacher confirmation make a draft of activities with the list as follows:

Guru memberi contoh dialog yang berkaitan dengan materi

[The teacher gives dialog example related to the material]

Guru memberi latihan berupa dialog yang masih kosong [The teacher gives an example of a dialogue related to the material]

Guru menyuruh melengkapi dialog yang masih kosong

The teacher asks to complete exercise of incomplete dialog 
Guru menyuruh siswa berlatih dialog dengan teman-temannya [Master instructs students to practice dialogue with their friends]

Guru mengawasi siswa yang sedang berdialog dengan teman-temannya [The teacher supervises the students who are in dialogue with his friends]

Guru bertanya tentang hal yang belum diketahui siswa

[The teacher asks about things the students have not yet learned]

Guru dan siswa bertanya jawab dan meluruskan kesalahpahaman

[Teachers and students ask questions and straighten out misunderstandings]

Guru menyuruh siswa tampil di depan kelas sendiri-sendiri

[The teacher asks the students to appear in front of their own class

Guru membangi siswa ke dalam beberapa kelompok

[Teachers engage students into groups]

Guru menyuruh siswa berdiskusi membuat sebuah dialog di dalam kelompok

[The teacher asks the students to discuss making a dialogue within the group]

Guru menyuruh setiap kelompok menampilkan dialog.

[The teacher asks each group to present a dialogue.]

Furthermore, the assessment of speaking skills listed in the lesson plan shows a lack of clarity of assessment indicators. This is seen by the three aspects of assessment, namely: knowledge, practice, and attitude with the same weight. Ideally, assessment for students at the primary level takes precedence over positive attitudes of learners such as going to the forefront of the class to dialogue with the theme to follow the activities compared with the demands of knowledge of the language.

\section{p. Media is not related to Basic Competency}

The description of this unrelatedness found that the media presented were not related to the basic competence of "conversations for approval" where the existing image media showed negative behaviors, such as: cheating, watching $\mathrm{TV}$ too closely, fighting, scolding, and others.

The existing image media is inconsistent with the expected competencies, such as competent conversation to ask and give permission, while the media draws on two people who dialogue in general.

\section{DISCUSSION}

The findings of the above research indicate that the Regulation of the Minister of National Education No. 41 of 2007 dated 23 November 2007 on Process Standards for Elementary and Junior Education Units has not been well implemented where the planning of the learning process which includes the syllabus and the lesson plan should reflect consistency, and the integration between its components. Syllabus as a reference for development contains the identity of subject or lesson theme, Standard Competence -Basic Competence, learning matters, learning activities, competency achievement indicators, assessment, time allocation, and learning resources. In the development of the syllabus needs to be considered several principles. The 
principle is a rule that will animate the implementation of kuri-lum level of educational unit. There are several principles that should be the basis for the development of this syllabus: scientific, relevant, systematic, consistent, adequate, actual / contextual, flexible, and comprehensive.

Furthermore, the lesson plan is outlined from the syllabus to direct the learning activities of learners in order to achieve basic competency. In order for the lesson plan to deliver expected results, there are principles of lesson plan preparation that need to be considered, namely: a) Taking into account individual differences of learners, b) Encouraging active participation of learners, c) Developing a culture of reading and writing, d) Providing feedback and follow up, e) The linkages and integrity of the lesson plan are prepared by considering the relevance and integration of $\mathrm{SK}, \mathrm{KD}$, learning materials, instructional learning, indicators of competency achievement, assessment, and learning resources in a unified learning experience, f) Implementing technology information and communication

Young Learners is defined by (Philips in Nagy, 2011: 1); Kasihani (2007: 15); Nunan (2005: 2); Mc Kay (2006: 1); and Lefever (2007: 27) can be a major consideration in developing learning process planning. Moreover, the characteristics of children according to Kasihani (2007: 15-20) at first liked the lessons related to their lives. In addition, children are still difficult to distinguish between concrete and abstract. Nevertheless, children love the imaginative things. Children are known for their favorite games, stories and songs. Also note that they have a feeling of boredom quickly. So the teacher should consider the diversity of learning activities.Another important point about the characteristics of early childhood, in their learning has not been fully able to cooperate in learning, but they are comfortable learning if there are friends nearby.

Another thing that is noticed by the prospective English teacher in primary school in planning the learning process is referring to English competency standard for elementary/Islamic junior high school as the local content. Through this English learning, elementary/Islamic junior high school graduates have a useful competence in preparing graduates to study English at junior / Islamic junor high school level. Ability is the ability to interact in English to support the activities of class and school.

English language education in elementay/Islamic elementay school is intended to develop the language skills used to accompany the action or the language accompanying action. English is used for interaction and is "here and now". The topic of conversation revolves around the things that exist in the context of the situation. To achieve this competency, learners need to be taught and familiarized with different kinds of adjacency pairs which are the basis for more complex interaction skills.

Attachment of Regulation of the Minister of National Education Number 16 Year 2007 regarding Academic Qualification Standard and Teacher Competence related to Foreign Language Teacher Competence, especially English Teacher Competence in elementary /Islamic elementary school as well as junior /Islamic junior high school, and senior/Islamic senior high school that an English teacher should: 1) have knowledge of various aspects of language in English (linguistic, discourse, sociolinguistic, and strategic) and 2) master English spoken and written, receptive and productive in all aspects communicative (linguistic, discourse, sociolinguistic, and strategic). Especially in learning English for children, a teacher is also required to have knowledge of the use of English in the classroom, apply certain techniques in the learning process, and know how to 
facilitate the learning process of children in a more enjoyable way. their ability to plan in writing in the form of learning process planning.

The purpose of English Language Subjects in elementary/junior high school is to enable learners to have the following skills: a) Developing communication competencies in a limited language-toaction format (language accompanying action) within the school context, b) Having awareness of the nature and importance of English for enhance the nation's competitiveness in a global society. The scope of English subjects in elementay/Islamic elementary school includes limited oral communication skills within the school context, covering the following aspects: 1) Listening, 2) Speaking, 3) Reading and 4) Writing. Writing and reading skills are directed to support oral communication learning.

\section{CONCLUSIONS AND RECOMMENDATIONS}

Referring to the formulation of research problems and findings, it can be concluded that the learning process planning documents designed by students of the English Tadris Study Program that follow the English for Children academic year 2013/2014 have not applied the principles of syllabus and development of the lesson plan.

Specifically the principle of consistency in the development of syllabus has been applied in the document, but still found some documents that do not show consistency between Basic Competence, Indicator, Learning Material, Learning Experience, Learning Resources and Assessment.

Furthermore, only a portion of the document has applied the principle of linkage and integration between the components in the lesson plan

For principles relating to learning English for children, it can be concluded that most have applied these principles, especially on helping students develop and practice language through collaboration and scaffolding.

Referring to the above findings, some suggestions for the parties directly related to the students' competence debriefing, especially in the planning of the learning process, such as lecturers, such as English Curriculum and Material Development, Methods of Teaching, Language Testing, and English for Children to continue to improve understanding and skills of students in designing syllabus and RPP, especially relating to the principle of consistency, relevance and integration, and principles related to learning English for children.

Furthermore, it is also suggested to the next researcher to conduct research related to the principles of syllabus and other lesson plan development to obtain a more comprehensive picture of the students' ability in planning the learning process.

such as lecturers, such as English Curriculum and Material Development, Methods of Teaching, Language Testing, and English for Children to continue to improve understanding and skills of students in designing syllabus and RPP, especially relating to the principle of consistency, relevance and integration, and principles related to learning English for children.

Furthermore, it is also suggested to the next researcher to conduct research related to the principles of syllabus and other lesson plan development to obtain a more comprehensive picture of the students' ability in planning the learning process.

\section{REFERENSI}

Cameron, Lynn. 2001. Teaching
Languages to Young Learners.
United Kingdom: Cambridge
Univercity.


Halliwell, Susan. 1992. Teaching English in the Primary Classroom. New York: Longman.

Lampiran Peraturan Menteri Pendidikan Nasional Nomor 41 Tahun 2007 Tanggal 23 November 2007 Tentang Standar Proses Untuk Satuan PendidikanDasar Dan

Mc.Closkey. 2005. Seven Instructional Principles for Teaching Young Learners Of English. Available in http://home.comcast.net/ educoatlanta/Handouts05/McCloskey_T ESOL Symposium02.pdf. Retrieved on 02 January 2012.

Peraturan Menteri Pendidikan Nasional Nomor 41 Tahun 2007 tanggal 23 November 2007 tentang Standar Proses untuk Satuan PendidikanDasar Dan Menengah

Sagala, Syaiful, Konsep dan Makna Pembelajaran, Cet. II, Bandung: Alfabeta, 2005.

Nagy Paula de. 2011. Issues and Contexts in Teaching Young Learners unit-1 Retrieved on 11 August 2011. Available in http://www.philseflsupport.com/youn g_learners.htm

Kasihani K. E. Suyanto. 2001. Improving a Course Design through Classroom Action Research. Jurnal Ilmu Pendidikan. Malang: Univeristas Negeri Malang.

Kasihani. K. E. Suyanto. 2007. English for Young Learner. Jakarta: Bumi Aksara.

Lampiran Peraturan Menteri Pendidikan Nasional Nomor 16 Tahun 2007 tentang Standar Kualifikasi Akademik dan Kompetensi Guru
Mc.Kay. 2005. Seven Instructional Principles for Teaching Young Learners of English. Available in http://home.comcast.net/ educoatlanta/Handouts05/McCloskey_TES OL_Symposium02.pdf. Retrieved on 02 January 2012.

Nagy Paula de. 2011. Issues and Contexts in Teaching Young Learners unit-1 Retrieved on 11 August 2011. Available in http://www.philseflsupport.com/youn g learners.htm

Rosenbusch, Marcia. 2000. Guidelines for Starting an Elementary School Foreign Language Program. ERIC Digest. September 2000.

Standar Kompetensi Guru, Bagian Komponen Pengelolaan

Pembelajaran dan Wawasan Kependidikan dan Komponen Pengembangan Profesi (2010), tersedia dalam http://www.geocities.com/pengemba ngan sekolah / standarguru.html . Retrieved on 10 September 2010.

Stocker, George. 2007. Teaching ESL to Children. Eslbase. http://www.eslbase.com/articles/eslchildren.asp. Retrieved on 12 January 201 